\title{
HUBUNGAN TINGKAT PENGETAHUAN TENTANG IMUNISAS POLIO DENGAN TINDAKAN MENGIMUNISASI POLIO DI POSYANDU ANGGREK DESA LANGENHARJO KELURAHAN LANGENHARJO KECAMATAN GROGOL KABUPATEN SUKOHARJO
}

\author{
Oleh : \\ Sri Aminingsih ${ }^{1}$ Diyono ${ }^{2}$ Pungky Nata Yolanda ${ }^{3}$
}

\begin{abstract}
The background of this study is that mothers in Anggrek posyandu not know exactly what it is polio symptoms and signs, so researchers wanted to know the mother's level of knowledge about polio immunization with polio immunization completeness action in posyandu Anggrek.

The purpose of the study to determine the relationship of the level of knowledge about polio immunization with polio immunizing action in posyandu Anggrek, Langenharjo Village, Village Langenharjo, Grogol, Sukoharjo, 2014.

The design of this study using desan research and cross correlation secsional. The subjects were mothers with infants aged at least 11 months in posyandu Anggrek as many as 33 people.

The results of the study of data obtained by distributing questionnaires and observation. The data have been collected and analyzed by chi square test with $p=0.05 p$ equal to 0.006 thus obtained $p$ value $<0.05$ which means $\mathrm{Ha}$ accepted.

Conclusion The results of the study indicate that there is a relationship between the level of knowledge about polio immunization with polio immunizing action in posyandu Anggrek Langenharjo Village, Village Langenharjo, Grogol, Sukoharjo, 2014.
\end{abstract}

Keywords: Polio Immunization Knowledge, Action Immunising Polio

\section{PENDAHULUAN}

Virus polio menular hanya dari orang ke orang yang terinfeksi virus, khususnya individu dengan tingkat kebersihan yang rendah. Pada tahun 2005 dalam waktu beberapa bulan, virus Polio menyebar ke beberapa provinsi di Indonesia sehingga mengakibatkan 307 anak lumpuh cacat seumur hidup.95\% dari semua penderita yang terinfeksi, tidak menunjukkan gejala tetapi mereka bisa menularkan kepada orang lain. Sekitar 4-8 \% infeksi poliovirus tidak menimbulkan gejala serius, hanya gejala minor seperti sakit tenggorokan, demam, lemah, gangguan pencernaan (sembelit) dan gejala umum lainnya seperti pada penyakit yang disebabkan oleh virus. Sekitar 1-2 \% individu yang terinfeksi berkembang menjadi poliomyelitis nonparalitik meningitis aseptik dengan kekakuan sementara pada leher, punggung atau kaki. Sedikitnya $2 \%$ dari semua korban infeksi polio akan menjadi lumpuh.

Di Posyandu Anggrek Desa Langenharjo, Kelurahan Langenharjo terdapat ibu yang mempunyai anak balita yang berjumlah 35 . Hasil wawancara dari 2 ibu di Posyandu tersebut mengatakan belum mengetahui secara pasti apa itu penyakit polio dan tanda gejalanya seperti apa.

\section{METODE PENELITIAN}


Dalam penelitian ini, peneliti menggunakan rancangan penelitian korelasi untuk mengetahui adanya hubungan antara tingkat pengetahuan tentang imunisasi polio dengan tindakan mengimunisasi polio di Posyandu Anggrek, Desa Langenharjo, Kelurahan Langenharjo, Kecamatan Grogol, Kabupaten Sukoharjo. Populasi pada penelitian ini adalah seluruh ibu yang mempunyai balita minimal usia 11 bulan di Posyandu Anggrek yang berjumlah 33 orang. peneliti menggunakan teknik sampling jenuh. Teknik Sampling jenuh adalah mengambil semua anggota populasi menjadi sampel. Analisa data dengan menggunakan $\mathrm{Uji} \mathrm{Chi}$ Kuadrat atau $\mathrm{x}^{2}$ untuk mengestimasi atau mengevaluasi frekuensi yang diselidiki atau menganalisis hasil observasi untuk mengetahui, apakah terdapat hubungan atau perbedaan yang signifikan pada penelitian tidak menggunakan data nominal.

\section{HASIL PENELITIAN}

Dari tabel distribusi frekuensi tingkat pengetahuan tentang imunisasi polio dapat diperoleh data bahwa tingkat pengetahuan tinggi menduduki jumlah terbanyak yaitu 23 responden dengan persentase $69,70 \%$ dan tingkat pengetahuan rendah menduduki jumlah paling sedikit yaitu 10 responden dengan persentase $30,30 \%$ sedangkan dari tabel distribusi frekuensi tindakan mengimunisasi polio dapat diperoleh data bahwa yang sudah melakukan tindakan imunisasi polio sebanyak 4X menduduki jumlah terbanyak dengan frekuensi sebanyak 30 responden dengan persentase $90,91 \%$ dan yang belum melakukan imunisasi sebanyak 4X menduduki jumlah responden paling sedikit dengan frekuensi sebanyak 3 responden dengan persentase $9,09 \%$.

Bila dilakukan analisa data dengan uji Chi-Square program SPSS versi
18.0 dengan $\alpha=5 \%(0,05)$ diperoleh $p$ sebesar 0.006 sehingga nilai $p<$ 0.05 , yang berarti $\mathrm{Ha}$ diterima sehingga ada hubungan antara tingkat pengetahuan tentang imunisasi polio dengan tindakan mengimunisasi polio di Posyandu Anggrek, Desa Langenharjo, Kelurahan Langenharjo, Kecamatan Grogol, Kabupaten Sukoharjo.

\section{PEMBAHASAN}

Tingkat Pengetahuan

Persentase tingkat pengetahuan tentang imunisasi polio yang paling tinggi adalah yang mempunyai tingkat pengetahuan tinggi dengan jumlah 23 responden $(69,70 \%)$ dan yang mempunyai tingkat pengetahuan rendah berjumlah 10 responden dengan persentase $(30,30 \%)$. Hal ini membuktikan bahwa tingkat pengetahuan ibu tentang imunisasi polio di Posyandu tersebut cukup tinggi. Hal tersebut dapat terjadi karena dipengaruhi beberapa faktor yaitu, faktor internal dan eksternal. Faktor internal itu sendiri meliputi pendidikan, pekerjaan, umur dan faktor eksternal itu meliputi faktor lingkungan dan sosial budaya.

Pengertian pengetahuan sendiri menurut beberapa pendapat ahli adalah hasil 'tahu', dan ini terjadi setelah orang melakukan pengindraan terhadap suatu objek tertentu. Penginderaan terjadi melalui pancaindra manusia, yakni: indra penglihatan, pendengaran, penciuman, rasa, dan raba. Sebagian besar pengetahuan manusia diperoleh melalui mata dan telinga. Pengetahuan atau kognitif merupakan domain yang sangat penting untuk terbentuknya tindakan seseorang (overt behavior). (Notoadmodjo, 2011)

Beberapa faktor yang mempengaruhi pengetahuan yang paling sering ditemukan peneliti saat melakukan penelitian adalah pendidikan dan usia. Pengaruh 
pertama yaitu pendidikan, hal ini dapat dibuktikan bahwa responden yang berpendidikan tinggi atau setara dengan SMA lebih mengetahui dan bisa menjawab pertanyaan berupa kuesioner yang peneliti bagikan kepada responden. Faktor kedua yaitu usia, hal ini dapat dibuktikan bahwa responden yang berumur 35-40 tahun ternyata mempunyai tingkat pendidikan rendah sehingga sulit menerima informasi, sebaliknya responden yang berumur 35 tahun kebawah mempunyai tingkat pendidikan tinggi sehingga mudah menerima informasi yang diberikan kepadanya.

Tindakan Mengimunisasi

Persentase tindakan mengimunisasi polio yang sudah dilakukan $4 \mathrm{X}$ berjumlah 30 responden dengan persentase $(90,91 \%)$ lebih tinggi dari pada tindakan mengimunisasi polio yang belum dilakukan $4 \mathrm{X}$ dengan jumlah 3 responden $(9,09 \%)$. Hal tersebut dapat terjadi karena beberapa faktor yaitu persepsi, motivasi, emosi, belajar.

Perilaku (manusia) itu sendiri adalah semua kegiatan atau aktivitas manusia, baik yang dapat diamati secara langsung maupun yang tidak dapat diamati oleh pihak luar. (Notoatmodjo, 2007)

Saat dilakukan penelitian ini peneliti menemukan beberapa faktor yang mempengaruhi tindakan mengimunisasi polio di Posyandu Anggrek, Desa Langenharjo. Faktor yang ditemukan oleh peneliti saat melakukan penelitian adalah faktor persepsi dan motivasi. Faktor pertama yaitu persepsi, hal ini dapat dibuktikan bahwa dari pengalaman responden melihat anak balita disekitar rumahnya yang mendapat imunisasi lengkap jarang terkena penyakit sebaliknya anak balita yang tidak melakukan imunisasi lengkap mudah terserang penyakit. Faktor kedua yaitu motivasi, hal ini dapat dibuktikan bahwa dengan pengalaman responden melihat anak balita yang mendapat imunisasi lengkap jarang terkena penyakit, responden termotivasi untuk melakukan imunisasi lengkap kepada anak balitanya agar tidak mudah terserang penyakit.

Hubungan Tingkat Pengetahuan Tentang Imunisasi Polio Dengan Tindakan Mengimunisasi Polio

Berdasarkan analisa bivariat hubungan tingkat pengetahuan imunisasi polio dengan tindakan mengimunisasi polio didapatkan hasil bahwa ada hubungan antara tingkat pengetahuan tentang imunisasi polio dengan tindakan mengimunisasi polio di Posyandu Anggrek Desa Langenharjo, Kelurahan Langenharjo, Kecamatan Grogol, Kabupaten Sukoharjo. Hal ini ditunjukkan dengan hasil uji ChiSquare program SPSS versi 18.0 dengan $\alpha=5 \%(0,05)$ diperoleh $p$ sebesar 0.006 sehingga nilai $p<$ 0.05 yang berarti Ha diterima.

Tingkat pengetahuan imunisasi polio dapat berhubungan dengan tindakan mengimunisasi polio karena semakin tinggi pendidikan seseorang semakin mudah menerima informasi sehingga dibuktikan dengan ibu melakukan tindakan imunisasi sebanyak 4 kali kepada anak balitanya. Pernyataan tersebut seperti yang dikemukakan oleh Adnani (2011), bahwa seseorang yang mempunyai pendidikan tinggi pasti mempunyai bentuk perilaku aktif yaitu bila perilaku tersebut jelas dapat diobservasi secara langsung. Oleh karena itu perilaku mereka sudah tampak dalam tindakan nyata (Overt Behavior).

\section{KESIMPULAN}

Dari hasil penelitian yang dilakukan pada ibu-ibu mengenai hubungan tingkat pengetahuan tentang imunisasi polio dengan tindakan mengimunisasi polio di Posyandu Anggrek Desa Langenharjo, 
Kelurahan Langenharjo, Kecamatan Grogol, Kabupaten Sukoharjo didapatkan hasil sebagai berikut:

1. Tingkat pengetahuan ibu tentang imunisasi polio di Posyandu Anggrek Desa Langenharjo, Kelurahan Langenharjo, Kecamatan Grogol, Kabupaten Sukoharjo diperoleh nilai ratarata yaitu 12,12 (kategori tinggi).

2. Tindakan mengimunisasi polio di Posyandu Anggrek Desa Langenharjo, Kelurahan Langenharjo, Kecamatan Grogol, Kabupaten Sukoharjo termasuk dalam kategori yang melakukan imunisasi sebanyak 4X yaitu 90,91\%.

3. Ada hubungan antara tingkat pengetahuan tentang imunisasi polio dengan tindakan mengimunisasi polio di Posyandu Anggrek Desa Langenharjo, Kelurahan Langenharjo, Kecamatan Grogol, Kabupaten Sukoharjo, dengan nilai uji chi-square $p$ sebesar 0,006 .

\section{SARAN}

1. Hendaknya orang tua memberikan imunisasi polio pada anaknya secara lengkap.

2. Hendaknya kader Posyandu memberikan penyuluhan kepada orang tua tentang pentingnya imunisasi polio secara lengkap.

3. Hendaknya petugas Puskesmas memberikan pendidikan kesehatan tentang pentingnya imunisasi polio.

\section{DAFTAR PUSTAKA}
Adnani, Hariza. Buku Ajar Ilmu Kesehatan Masyarakat. Yogyakarta: Nuha Medika, 2011.

Cahyono, Suharjo B., et al. Vaksinasi Cara Ampuh Cegah Penyakit Infeksi. Yogyakarta: Kanisius, 2010.

Cave, Stephanie dan Deborah Mitchell. Orang Tua Harus Tahu Tentang Vaksinasi Anak. Alih bahasa Susi Purwoko. Jakarta: Gramedia, 2003.

Dewi, M dan A. Wawan. Teori dan Pengukuran Pengetahuan Sikap dan Perilaku Manusia. Yogyakarta: Nuha Medika, 2011.

Fitriani, Sinta. Promosi Kesehatan. Yogyakarta: Graha IImu, 2011.

Hidayat, A.Aziz Alimul. Metodolgi Penelitian Keperawatan dan Teknik Analisis Data. Jakarta: Salemba Medika, 2009.

Pengantar IImu Kesehatan Anak untuk Pendidikan Kesehatan. Jakarta: Salemba Medika, 2009.

Riset Keperawatan dan Teknik Penulisan IImiah. Jakarta: Salemba Medika, 2003.

Riset Keperawatan dan Teknik Penulisan IImiah. Jakarta: Salemba Medika, 2008. 
Notoatmodjo, Soekidjo. Promosi Kesehatan dan IImu Perilaku. Jakarta: Rineka Cipta, 2007.

. Kesehatan Masyarakat IImu dan Seni. Jakarta: Rineka Cipta, 2011.

Riwidikdo, Handoko. Statistik untuk Penelitian
Kesehatan dengan Aplikasi Program $R$ dan SPSS. Yogyakarta: Pustaka Rihama, 2009.

Suyanto. Metodologi dan Aplikasi Penelitian Keperawatan. Yogyakarta: Nuha Medika, 2011.

Dosen AKPER Panti Kosala Surakarta

2 Dosen AKPER Panti Kosala Surakarta

3 Mahasiswa AKPER Panti Kosala Surakarta 